\title{
SPECIFIC EDUCATIONAL INTERVENTIONS IN THE REHABILITATION OF COGNITIVE CAPACITIES OF ADULTS DUE TO A CEREBROVASCULAR ACCIDENT (EXPERIMENTAL INVESTIGATION)
}

\author{
Aurelia Glavan, \\ neurologist at Institute of Emergency Medicine, PhD in psychology, associate professor at Tiraspol \\ State University, Republic of Moldova, ORCID ID: https://orcid.org/0000-0002-2549-5367
}

DOI: https://doi.org/10.31435/rsglobal_ws/30062020/7121

\section{ARTICLE INFO}

Received: 15 April 2020

Accepted: 09 June 2020

Published: 30 June 2020

\section{KEYWORDS}

cognitive functions, cerebrovascular accident (CVA), stroke, cognitive rehabilitation, Reuven Feuerstein, mediated learning, social inclusion, quality of life.

\begin{abstract}
An optimal cognitive functionality ensures the efficiency of day-to-day activities and a person's integration into the socio-economic environment. Cognition is not a unitary concept, it incorporates several domains: attention, memory, executive functions, perception and praxis, language. Cognitive functions are affected as a result of a cerebrovascular accident (CVA), manifested by a prevalence of $20 \%$ to $80 \%$ after a stroke. We have proposed an experimental investigation - the use of the Reuven Feuerstein theory in the cognitive rehabilitation of post-stroke individuals, thus overcoming the social disadvantage and contributing to improving their quality of life, through social inclusion. The principle of mediated learning has proven to be effective in improving the cognitive abilities of post-stroke individuals in addition to medical treatment, representing an alternative service offered by the specialists in cognitive therapy, thus being a quick and cost-effective way of recovering.
\end{abstract}

Citation: Aurelia Glavan. (2020) Specific Educational Interventions in the Rehabilitation of Cognitive Capacities of Adults Due to a Cerebrovascular Accident (Experimental Investigation). World Science. 6(58), Vol.3. doi: $10.31435 /$ rsglobal_ws/30062020/7121

Copyright: (C) 2020 Aurelia Glavan. This is an open-access article distributed under the terms of the Creative Commons Attribution License (CC BY). The use, distribution or reproduction in other forums is permitted, provided the original author(s) or licensor are credited and that the original publication in this journal is cited, in accordance with accepted academic practice. No use, distribution or reproduction is permitted which does not comply with these terms.

Introduction. Cognitive functions are active in all the aspects of a human being's existence. The optimal cognitive functioning ensures the efficient development of all daily activities and a person's integration into its socio-economic environment. Cognition is not a unitary concept, it incorporates several cognitive domains: attention, memory, executive functions, perception and praxis, language $[6 ; 8]$.

Professor Reuven Feuerstein, also called the "Einstein of Contemporary Pedagogy", born in Romania, the author of the theory of cognitive modifiability and the theory of mediated learning, was an advocate of the theory that intelligence can be learned. Being a professor at Bar Ilan University in Ramat Gan and Vanderbilt University, he had the privilege of working with the world's best psychologists, specialists in development psychology such as J. Piaget and L. Vygotsky. The Feuerstein Method is a point of reference for psycho-pedagogic intervention programs applied in various contexts. In order to help with the solving of existing complex social problems, Feuerstein, through his position as a psychologist, convinced that the human being is modifiable, has proposed to overcome situations of social disadvantage [7]. Feuerstein's theory is based on concepts of the learning potential and structural-cognitive modifiability, followed by a dynamic practical intervention. Starting from Piaget and Vygotsky's theories, Feuerstein is not only interested in analyzing the functioning of intelligence itself, but also in intelligence as a human resource that can be enriched and improved. 
Feuerstein investigates specifically how to overcome cognitive retardation, emphasizing that the presence of a good mediator, able to fully develop the subject's abilities, can significantly reduce (sometimes even cancel) the disability. Feuerstein [3; 4] pointed out repeatedly that the man is able to change even if he has a deficiency. Socially disadvantaged or disabled people are not capable of a spontaneous change. In their case, an intensive systematic intervention is needed.

The Feuerstein Method has been used in over 30 countries across the world, for more than 70 years, and the fact that it has stood the test of time proves its value and importance. Nowadays, the method is used in various areas: in the formal educational field (secondary-schools and universities), in special psycho-pedagogy (the recovery of people with socio-cultural integration problems), in the education of adults (maintenance of the mental capacities of the elderly and of people with neurological cognitive impairments) and in the continuous training (professional qualification of the working staff).

The Feuerstein Method [3] is characterised by a strong action impulse and operationality. Unlike many specialists who deal with disabled persons and who often say that they are faced with obstacles that are difficult to overcome due to the severity of their situation, Feuerstein [4] claims that the development of an individual's cognitive abilities is alway possible, regardless of: 1.Age of the subject (Feuerstein argues that we can induce structural cognitive changes in adults). Feuerstein disagrees with the idea of a so-called "critical period", after which a disabled person can not show a learning progress anymore. The cognitive decline of an adult with disabilities is caused by the absence of specific educational interventions and is possible to overcome. 2.The etiology of the disability (Feuerstein [3] argues that an intervention of cognitive improvement is possible in any case). 3.The severity of the deficiency (All the rehabilitation methods are justified in the possibility of boosting the cognitive and behavioral abilities of the subject). In the Feuerstein Method this opportunity is asserted beyond any obstacle [3].

The concepts: learning potential, cognitive modifiability and mediation are the fundamentals of Reuven Feuerstein's psychological theory. The learning potential is a total of latent virtual behaviours that require some involvement to be transformed into actions. The cognitive modifiability deals with a human's ability to change his own structure of cognitive functioning in order to adapt to situations that arise throughout life [8;18]. Mediation is defined as the deliberate active intervention that the educator offers to the people with whom he interacts, aiming at the best possible development of their capacities and their gradual attainment of autonomy. According to the theory of modifiability and mediation, the learning process is the root of higher mental functions, where the educator has the fundamental role [4]. The way of interaction between environment, educator and individual underlies the most of the structural changes that occur in the human cognitive apparatus. The mediator must be able to identify, choose and determine some of the stimuli that reach the subject, in order to make them accessible. The educator will not interfere between the subject and the outside world, its role is to identify the stimuli that need to be adapted for their optimal exploitation, to focus on the relevant data, determining the interest, attention and awareness [3;9].

\section{Using the Reuven Feuerstein Theory for the cognitive rehabilitation of individuals after a cerebrovascular accident}

The Reuven Feuerstein Theory [3], like other theories emerging from the need to assist people in difficulty, has proven to be useful for the entire population. Therefore, the principle of mediated learning has also shown to be effective to improve the cognitive capacities of adults following a cerebrovascular accident (CVA). The cognitive functions are affected as a result of a cerebrovascular accident [11], with the cognitive impairments showing a prevalence of $20 \%$ to $80 \%$ post-stroke. The cognitive deficit after a CVA is encountered in literature as a vascular cognitive deficit, a generic term that has been used to describe a broad spectrum of cognitive changes related to vascular disorders [15]. The cognitive deficit after a stroke is reversible, approximately $16 \%$ to $20 \%$ of CVA survivors show an improvement of their cognitive impairment during the first three months, with a recovery that could last for at least a year post-stroke. There are numerous studies conducted so far in order to identify the cognitive domains primarily affected by stroke. Tatemichi [16] and other specialists [5; $17 ; 19]$ have defined a general profile of the problems that emerged, with reference to the cognitive domains affected by a stroke: attention, memory, executive functions, perception and praxis, language [2; 11]. The remaining cognitive deficits after a CVA may concern one or more cognitive areas and are directly related to the severity of the cerebrovascular accident. Persons with post-stroke disabilities, psychologically scarred by the traumatic experience of the disease, need alternative 
interventions to medication in solving the existing social problems $[1 ; 6 ; 12 ; 13]$. An important advancement in the cognitive rehabilitation of post-stroke individuals can be achieved by using the Feuerstein method, based on the concepts of learning potential and structural-cognitive modulation, followed by a dynamic practical intervention.

Experimental investigation: Applying the tools from the Instrumental Enrichment Program developed by Reuven Feuerstein in post-stroke patients. Through the validation of the hypothesis, the investigation aimed to contribute to the improvement of the practical ways of social inclusion of persons post CVA, in order to integrate them into their families, professional and social lives.

The aim of the investigation was the social inclusion of individuals after a stroke, for the purpose of family, professional and social integration, by using the tools of the Instrumental Enrichment Program by Reuven Feuerstein.

The hypothesis of the research was the assumption that applying the appropriate instruments, from the Instrumental Enrichment Program developed by Reuven Feuerstein, favors a faster social inclusion of individuals after a CVA.

The objectives of the investigation were 1 . The neuropsychological evaluation of post-stroke patients; 2. The adjustment of the therapeutic intervention strategy to post-stroke patients; 3 . The implementation of the Instrumental Enrichment Program by Reuven Feuerstein in order to promote the social inclusion of post-stroke individuals.

Approaches: systematic observation; the interview; methods of medical document research; the case study; statistical analysis of data.

The research materials: the psychological evaluation form devoted to people in the process of post-stroke recovery; Psychological tests used for data collection: Montreal Cognitive Assessment (MoCA); Wechsler Memory Scale (WMS); Clock Drawing Test (CDT); Stroke Specific Quality of Life Scale (SSQoL); Logopedic evaluation form; Porteus Maze Test.

Study groups: According to the classic design of the experimental investigation, two samples were needed for conducting the research, as follows: experimental group - included post-stroke patients, who were diagnosed clinically and paraclinically and who were given a proper set of tools from the Instrumental Enrichment Program by Reuven Feuerstein, aimed at the social reintegration of post-stroke individuals; control group - included post-stroke patients who were diagnosed clinically and paraclinically, but who did not benefit from the means of Reuven Feuerstein's Instrumental Enrichment Program. The study took place within the Neurology Section "Cerebrovascular Diseases" of the Institute of Emergency Medicine, during 2016-2018. A total of 160 patients were investigated. 20 patient were enrolled in the Feuerstein experiment, to whom the tools from the Instrumental Enrichment Program have been applied over a period of one year.

\section{Results, comments, conclusions.}

There were 160 post-stroke patients enrolled in the experimental study, the Reuven Feuerstein Instrumental Enrichment Program was applied to 20 patients who met the mentioned criteria. The results of the Feuerstein method were very good, allowing the patients a faster and complete social reintegration, leaving the hospital and continuing their recovery at home, thus reducing the costs of a prolonged hospitalization. These cases highlight the fact that each person has a chance of recovery, but the individual progress of each patient (time, efficiency, costs, services) depends on objective and, especially, on subjective factors, specific to each individual. Good and very good results were achieved by 17 patients. The number of instruments that were used, their rate of implementation and the time period in which the intervention was applied were different, tailored to the individual features of each patient, so that the achieved results enabled the optimal reintegration into their family, society and work environment, consistent with the objectives planned by the therapeutic team members. Regarding the mental abilities of the patients, the impaired mental functions were successfully activated, with significant results being recorded in the output stage, where higher cognitive and metacognitive levels were recorded after the input stage, where the deficiencies caused by the neurological condition were recorded, and the development stage, in which a set of tools, belonging to the Instrumental Enrichment Program developed by Reuven Feuerstein, were applied. The average hospital stay of the 20 patients enrolled in the study was 23 days, the Feuerstein recovery method being continued at the patients' home. The Feuerstein method was applied to a total of 20 patients, out of which $85 \%$ had a good and a very good outcome, only $15 \%$ experienced regression due to neurological complications that occurred during treatment, regardless of the recovery method that was used. 
The results of the Feuerstein method predict the possibility of a quick recovery with minimal costs, the program can also be carried out at the patient's home, who besides drug treatment, can choose alternative services provided by the specialists in cognitive therapy.

The cognitive optimization intervention, designed according to the Feuerstein Method and individualized, leads to the adjustment of the parameters that measure cognitive performance in people who have suffered a cerebrovascular accident.

The individualisation of the cognitive optimization intervention, according to the specific needs of each cognitive domain, ensures the success of the therapeutic approach, regardless of whether the person is in the subacute or chronic post-stroke stage.

Working with the patient in order to determine the purpose and objectives of the recovery program, ensuring his compliance and active participation in the therapeutic interventions are mandatory for the augmentation of the recovery benefits, increasing the cognitive performance indices, being both results and catalyst factors for any recovery intervention, with all the advantages to the quality of life.

\section{REFERENCES}

1. Canevaro A. Pedagogia speciale: la riduzione dell'handicap, Bruno Mondadori, Milano, 1999. p. 22 - 30

2. Conti J, Sterr A, et all, Diversity of approaches in assessment of executive functions in stroke: limited evidence?", eNeurologicalSci. 2015;1(1), p. 12-20

3. Feuerstein, R., Rand, Y., Hoffman, M. B., Miller, R., Instrumental Enrichment: an intervention program for cognitive modifiability, Baltimore University Park Press, Baltimore, USA,1980, p.124- 200

4. Feuerstein, R.; Falik, L.H.; Rand, Y. The Dynamic Assessment of Cognitive Modifiability: the learning propensity assessment device: theory, instruments and techniques. Jerusalem: The ICELP Press, 2002, 18-33

5. Hochstenbach J, Mulder T, et all, Cognitive decline following stroke: a comprehensive study of cognitive decline following stroke. J Clin Exp Neuropsychol 1998; 20, p.503-517

6. Joiţa, E., Educaţia cognitivă. Fundamente. Metodologie, Editura Polirom, Iaşi, România, 2002, 67-82

7. Kopciowski Camerini, J., L'apprendimento mediato. Orientamenti teorici ed esperienze pratiche del metodo Feuerstein, La Scuola, Brescia, Italy, 2002, p. 7-8

8. Manolache I., O inovație în psihopedagogie. Teorie și practica schimbării cognitive, în Revista de Psihologie, nr. 4, 1992, p. 9-12

9. Mara D., Învăţarea mediată - abordări teoretice şi practice, în „Problematica învăţare-evaluare: abordări, studii, cercetări”, (coord. Popescu, Rodica), Editura Psihomedia, Sibiu, 2009, pp. 216

10. Mara D., Strategii didactice în educaţia incluzivă, Editura Didactică şi Pedagogică, Bucureşti, 2004, p. 5-11

11. Marin A.G., Seiciu P.L., Popescu A.M., Bighea A., Berteanu M. „Technology for post-stroke cognitive rehabilitation"., IJPMBS, Vol.4, No. 2, Aprilie 2015, ISSN: 2278-5221, pp. 146 - 150

12. Moraru A., Pascal O., Hamițchi E., Munteanu L., Agapii E., Cojocari D., Cebotari A., "Reabilitarea medicală a bolnavului cu accident vascular cerebral - Protocol Clinic național. PCN -181" aprobat de Ministerul Sănătății al Republicii Moldova, Chișinău, 2012, Rev. 2014, pag. 8, http://inn.md/sites/default/files/reabilitareaavc. pdf (Cap. C.2./Caseta 36 - Recuperarea cogniției, p.46)

13. Popoviciu DV, Mitu P., Reforma norvegiană privind integrarea persoanelor handicapate, în Revista de Educaţie Specială, nr. 2, 1992, p. 13-21

14. Sun J-H, Tan L, Yu J-T.,"Post-stroke cognitive impairment: epidemiology, mechanisms and management",Annals of Translational Medicine. 2014;2(8), p.80

15. Tang W.K., Chen Y.K., Wong K.S.,"Absence of cerebral microbleeds predicts reversion of vascular cognitive impairment no dementia' in stroke", Int J Stroke. 2011 Dec; 6(6), p.498-505

16. Tatemichi et all,"Cognitive impairment after stroke: frequency, patterns and relationship to functional abilities", J Neurol Neurosurg Psychiatry 1994;57, p. 202-207

17. Teasell R, Hussein N,"Rehabilitation of Cognitive Impairment Post Stroke", Stroke Clinician Handbook, 2014, p.1-41

18. Verza E, Păun E., Educaţia integrată a copiilor cu handicap, UNICEF şi RENINCO, Bucureşti, 1998, p. 5-9

19. Wong GKC, Lam SW, Ngai K, et al.,"Cognitive domain deficits in patients with aneurysmal subarachnoid haemorrhage at 1 year", J Neurol Neurosurg Psychiatry 2013;84, p.104-105 